\title{
Raw material studies of West Central Serbia
}

\author{
Vera Bogosavljević Petrović ${ }^{1}$ and Jelena Marković ${ }^{2}$ \\ National Museum in Belgrade. Trg Republike 1a, 11000 Belgrade, Serbia. \\ Email: Bogosavljević Petrović: v.bogosavljevic@ narodnimuzej.rs; Marković: j.markovic@ narodnimuzej.rs
}

\begin{abstract}
:
This paper deals with raw material problems in the territory of West Central Serbia geologically determined as the Čačak-Kraljevo (or West Morava) basin. Our research is presented through the most striking case studies, Lojanik, Vlaška Glava and Lazac.

The Lojanik hill is a silicified forest by origin. It has occasionally been in use from the earliest periods of prehistory until today as a source of black and ochre-coloured flint, opal and silicified wood. A detailed prospection, including the mapping of surface finds using square nets, was conducted during two research campaigns.

The Vlaška Glava is an open-air Palaeolithic site at which artefacts made of white, ochre, red, brown and black chert, silicified magnesite, volcanic and metamorphic rocks were found. Our research of primary and secondary geological deposits in the vicinity of the site showed equivalent raw material. We also found an interesting primary deposit of high quality bluish grey flint with outcrop activities (Workshop 1).

The Lazac shaft is a contemporary magnesite mine, recently abandoned because of the high percentage of silicon-dioxide. We determined the same raw material in collections found at nearby Neolithic sites. Certain similarities between the wooden support systems of ore exploration in the Middle Ages and modern times were established at the entrance of the shaft.

Our research in the territory of the West Morava basin resulted in reconstruction of some links between geological deposits and settlements and also creation of a relevant base for future raw material studies.
\end{abstract}

Keywords: raw material; chert; mine; quarry; geological deposits; West Central Serbia

\section{Introduction}

The territory of West Central Serbia represents a diverse area, comprising the rivers of West Morava and Ibar with a lot of tributaries and mountains of different geological origin (Figure 1). A large number of micro-region-type small units have provided an optimal space for living. The area, geographically limited in this way, coincides with a complex geologically determined as the Čačak-Kraljevo (or West Morava) basin. This basin extends to about 1000 $\mathrm{km}^{2}$ filled mostly with Miocene and Quaternary sediments, whose thickness reaches $2000 \mathrm{~m}$ (Pavlović et al. 1977:270). In terms of morphology, the basin is a tectonic depression, whose formation is predisposed by deep faults. The surface of the basin is slightly rolling varying

Published by the School of History, Classics and Archaeology, University of Edinburgh ISSN: 2055-0472. URL: http://journals.ed.ac.uk/lithicstudies/

This work is licensed under a Creative Commons Attribution 2.5 UK: Scotland License. 
from 340 to $550 \mathrm{~m}$ with more pronounced relief in the periphery. The geotectonic position of the basin is within a zone of the Inner Dinarides. Its direction is northwest-southeast of the Dinaric type. Palaeo-relief of the basin bottom is formed from the various rocks (Figure 2).

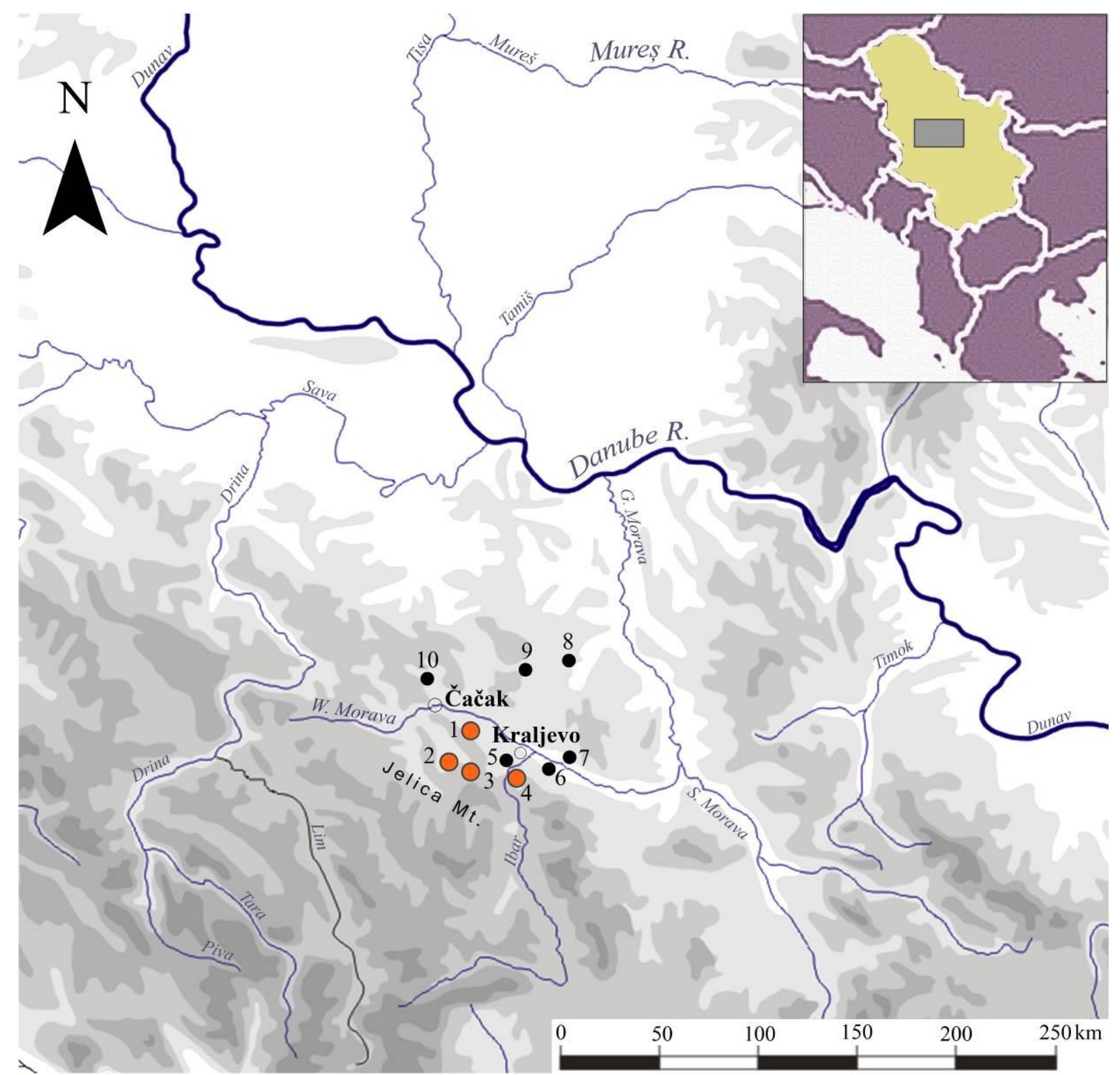

Figure 1. Map of West Central Serbia with archaeological sites mentioned in text. 1. Vlaška Glava; 2. Workshop I; 3. Lazac mine; 4. Lojanik mine; 5. Crkvine; 6. Divlje polje; 7. Okruglica; 8. Divostin; 9. Grivac; 10. Trsine.

The northeast boundaries mostly consist of volcanic rocks (andesite, dacite, quartz latite, latite, basaltic andesite, trachybasalt, and pyroclastic rocks), serpentinite and Upper Cretaceous Flysch, which are much less represented. The south rim of the basin is composed of Lower Palaeozoic formations (quartz conglomerates, metamorphic sandstone, phyllites and argiloschistes/shales), Middle and Upper Triassic sediments (schistose limestone, bedded limestone with cherts, dolomites and massive limestone), diabase-chert formations (arenites, mudstone, cherts, biomicrites and diabase), and Upper Cretaceous layered and bedded limestone and volcanic rocks (dacite and andesite with pyroclastic rocks). Serpentinite and diabase are dominant in the formation of the west edge of palaeo-relief, while the diabasechert formations are much less present (Novković 1975:122). 


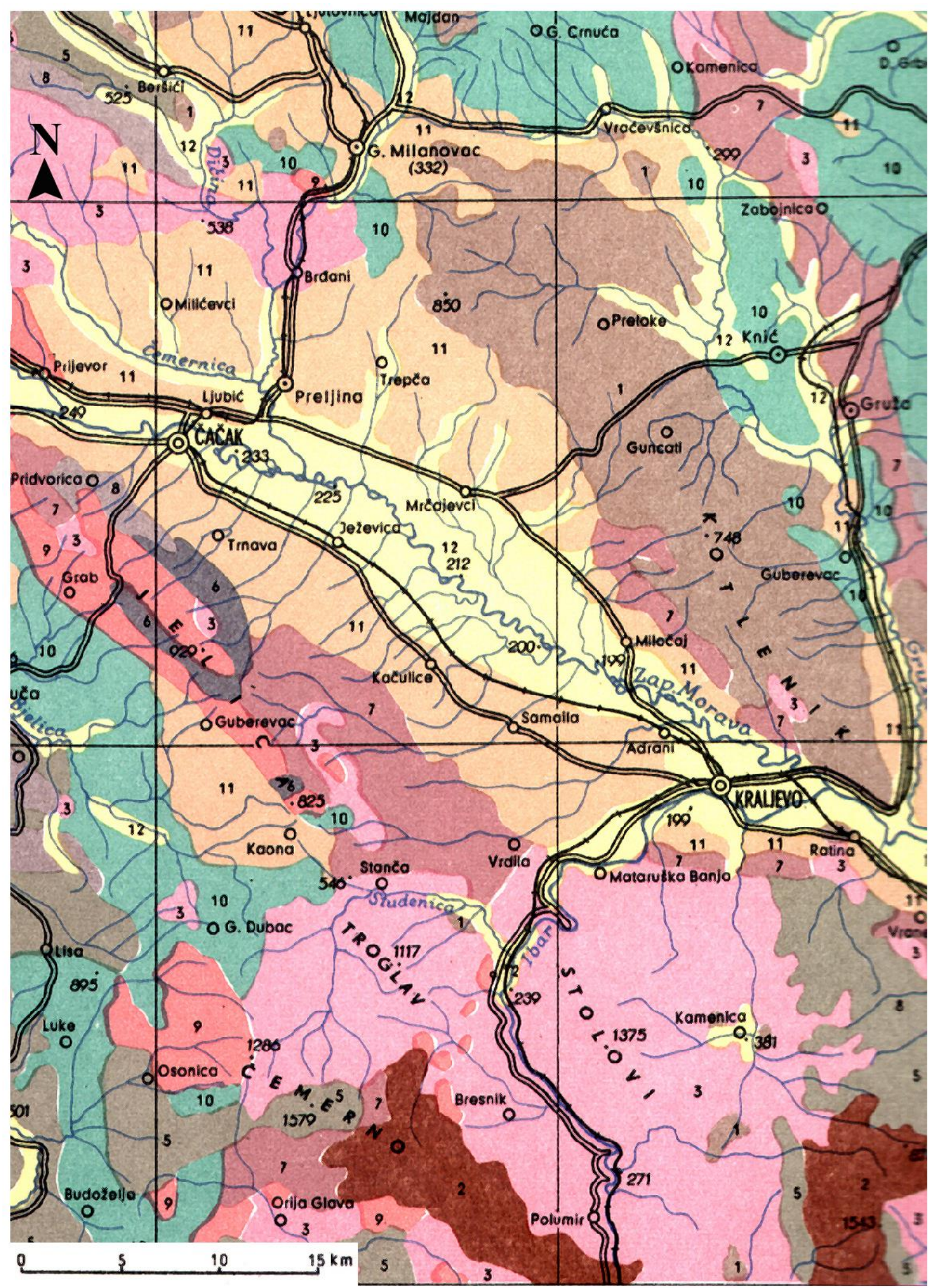

Figure 2. Geological map of the Čačak - Kraljevo Basin. 1. magmatic surface rocks (volcanites) and dust; 2. magmatic deep rocks (plutonian); 3. serpentines and peridotites; 4. loess and loess-like formations; 5. slates of lower crystalite; 6. slates of non-crystal rocks; 7. fixed clastic sediments; 8. calcareous rocks; 9 . diabase-quartz formation; 10. flysche and flysche-like formations; 11. pelites; 12. fluvial sediments. (Map based on ISS 1966.) 
In this region abundant in raw material, the number of so far archaeologically identified sites is quite high. Unfortunately, the number of sites that have been archeologically explored is much lower. The remains of the Lower and Middle Palaeolithic have been found at the open-air site - Vlaška Glava in the nearby village Samaila (Figure 1). The largest number of sites belongs to the Neolithic and Chalcolithic: Crkvine, Lojanik, Okruglica, Divlje Polje and the sites in the Lazac area. There is also a high density of Roman and Medieval sites.

In general, petroarchaeological studies of Serbia have not been conducted systematically and thoroughly. Only fragmentary works at certain sites and areas, mostly based on geological maps and literature, have been done so far (Bogosavljević Petrović \& Marković 2012). The first petroarchaeological studies of West Central Serbia were done in the eighties of the $20^{\text {th }}$ century, during the exploration of Neolithic collections from Divlje Polje and Okruglica sites (Valović 1983; 1987). Through the collaboration between the archaeologist S. Valović, and later V. Bogosavljević Petrović and petrologist D. Stojanović, basic classes of stone raw materials were determined in the context of their origin. The results of the identification initiated further research of exploited geological deposits (Bogosavljević 1987; Stojanović 1987; Bogosavljević 1990). That is how the survey of the zone of a silicified forest started, as well as collecting of the waste mining materials from modern extraction on the Lojanik hill. Another contemporary location, the Lazac mine, is a good example of magnesite exploitation and the methodology of underground gallery netting.

The most striking case studies presented in this paper will show the importance of the territory of West Central Serbia for the reconstruction of the social and palaeo-economic aspects of the stone raw materials exploitation strategy in the prehistory.

\section{The Lojanik mine}

Lojanik is a hill near the modern settlement Mataruška Banja, i.e. the thermal spa in the central part of the Čačak-Kraljevo basin. Today, as a site, Lojanik represents an archaeological and natural heritage monument as well. Geologically, it was formed by different tectonic processes and the silicification of an ancient forest during the Miocene and Quaternary. Besides the silicified coniferous and deciduous trees, there are opals made by hydrothermal processes, too (Pavlović et al. 1977: 270-275).

The archaeological site at Lojanik was identified some 25 years ago, and so far it has been studied without continuity (Bogosavljević 1992:9, 26; Bogosavljević-Petrović 2005:92102). The traces of ancient mining works are visible on all slopes of the hill. During our fieldwork, a significant number of artefacts were collected. The finds led to the conclusion that the Lojanik slopes have been the place of stone exploitation since the earliest periods of prehistory until today. A few different forms of mining were observed on the surface configuration, such as circular depressions, with conical profile by the rule (deriving from vertical mineshafts) (Figure 3/b), rectangular depressions, deriving from test mining trench (Figure 3/c) or filled pits of the mine entrances (Figure 3/a). Deposits of waste products were found all around the shafts. Workshops with debitage, some cores and tools were also recorded near the places of extraction.

A detailed prospection, including the mapping of surface finds using square nets, was conducted during two research campaigns. The first one, as small-scale research, was done during 2004 by the National Museum in Kraljevo. The prospection surface Net 1 covered 15 $\mathrm{m}^{2}$ with eight loci containing 1500 finds in total (Bogosavljević Petrović 2005: Figure 5). Ten years later, in 2013, as a part of the National Museum in Belgrade project $^{1}$, a new prospection started. Net 2 spread on $24 \mathrm{~m}^{2}$ with 2500 artefacts. During both campaigns, technologically and typologically defined artefacts were found: pre-cores, cores of different types and their fragments, cortical and massive flakes, flakes of an advanced stage of reduction, waste 
products, chips, rejuvenation flakes and blades (tablets, crested blades), as well as different types of retouched tools, most usually massive scrapers and side-scrapers (Figure 4). Based upon distribution and artefacts analyses, an important conclusion was made - the existence of raw material preliminary selection and the workshop that lasted for a long time in the close vicinity of an outcrop.
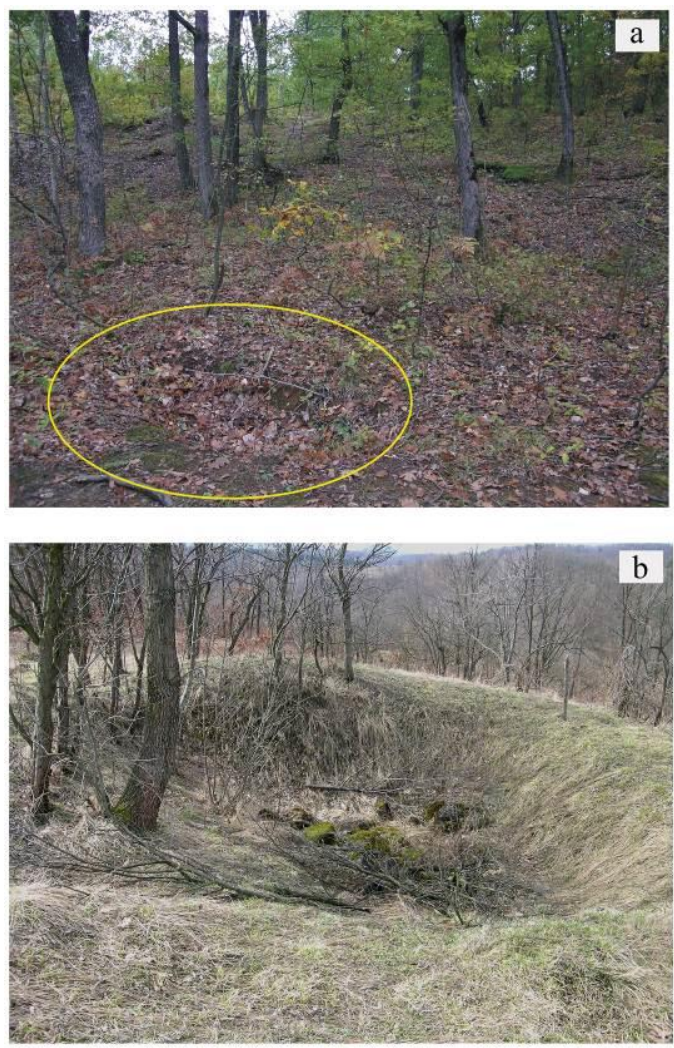

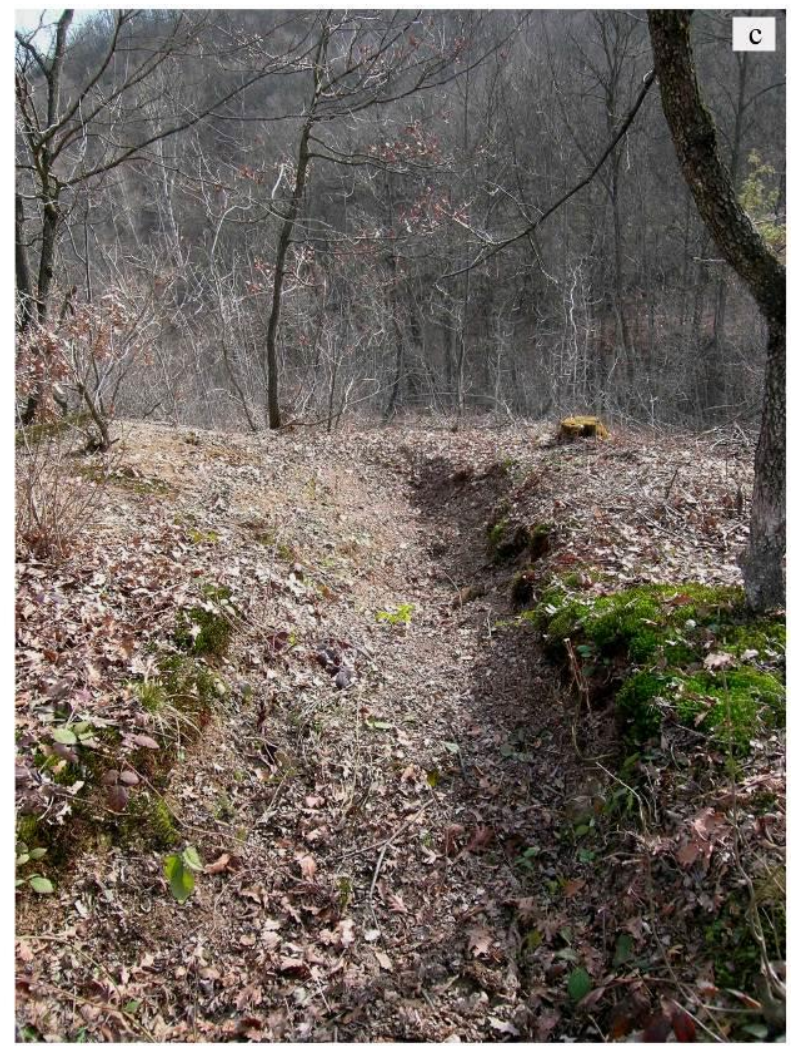

Figure 3. Lojanik Hill. Surface forms of mining. a. pit; b. circular depression; c. rectangular depression.
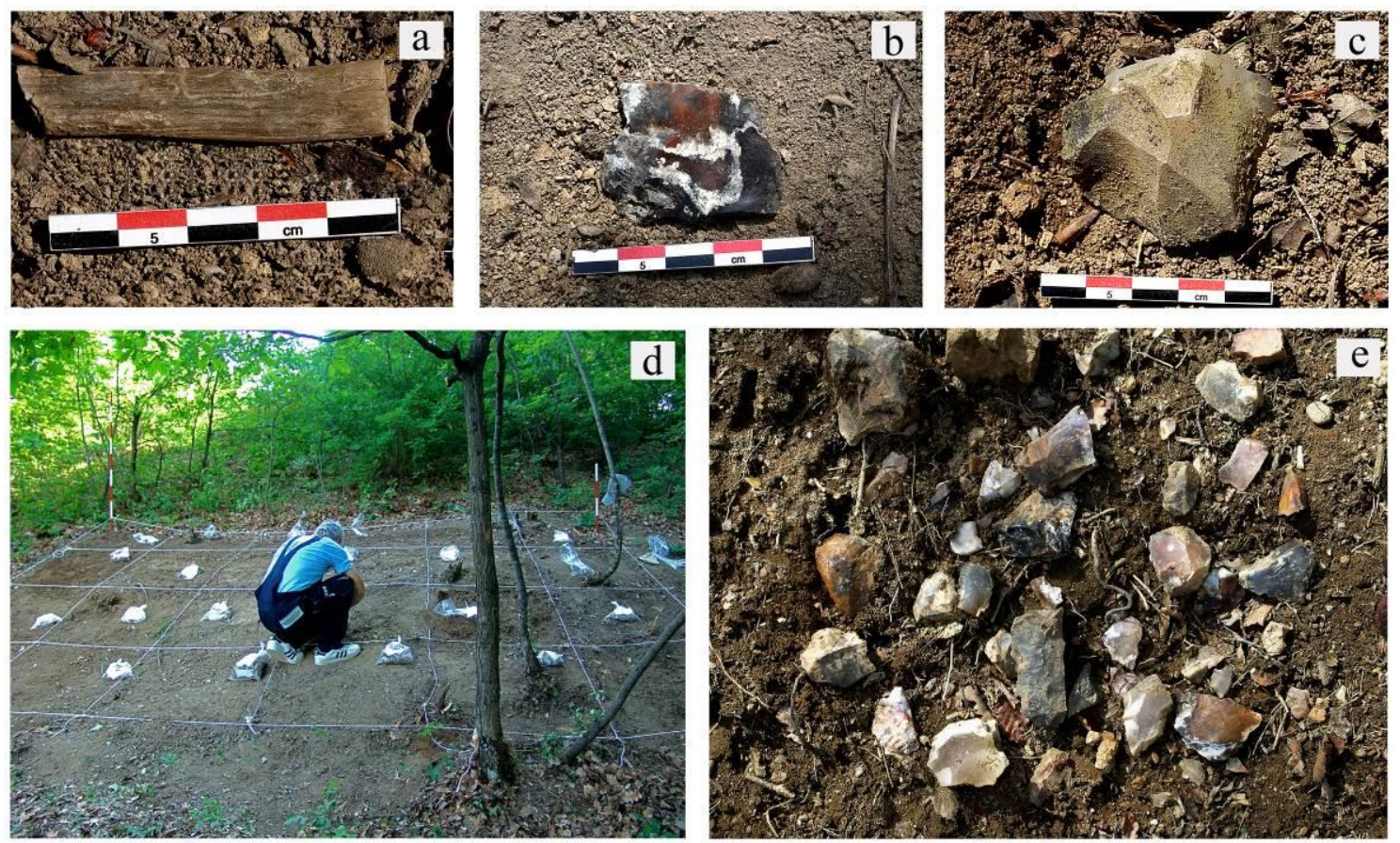

Figure 4. Lojanik Hill. Prospection. a, b, \& c. artefacts; d. square net, e. example of surface artefact spreading. 
Different raw materials can be found on Lojanik of which the most frequent are black and ochre-colour flint, opal and silicified wood. Comparing this raw material with artefacts from archaeological sites of the surrounding area showed a high degree of similarity. In the Early Neolithic stratum at the site Crkvine and the Late Neolithic-Early Chalcolitic Vinča culture site Divlje Polje (Figure 1), the artefacts made of black and ochre-colour flint were found (Figure 5). Also, the silicified wood was identified in the assemblage from the Divlje Polje site (Figure 5).

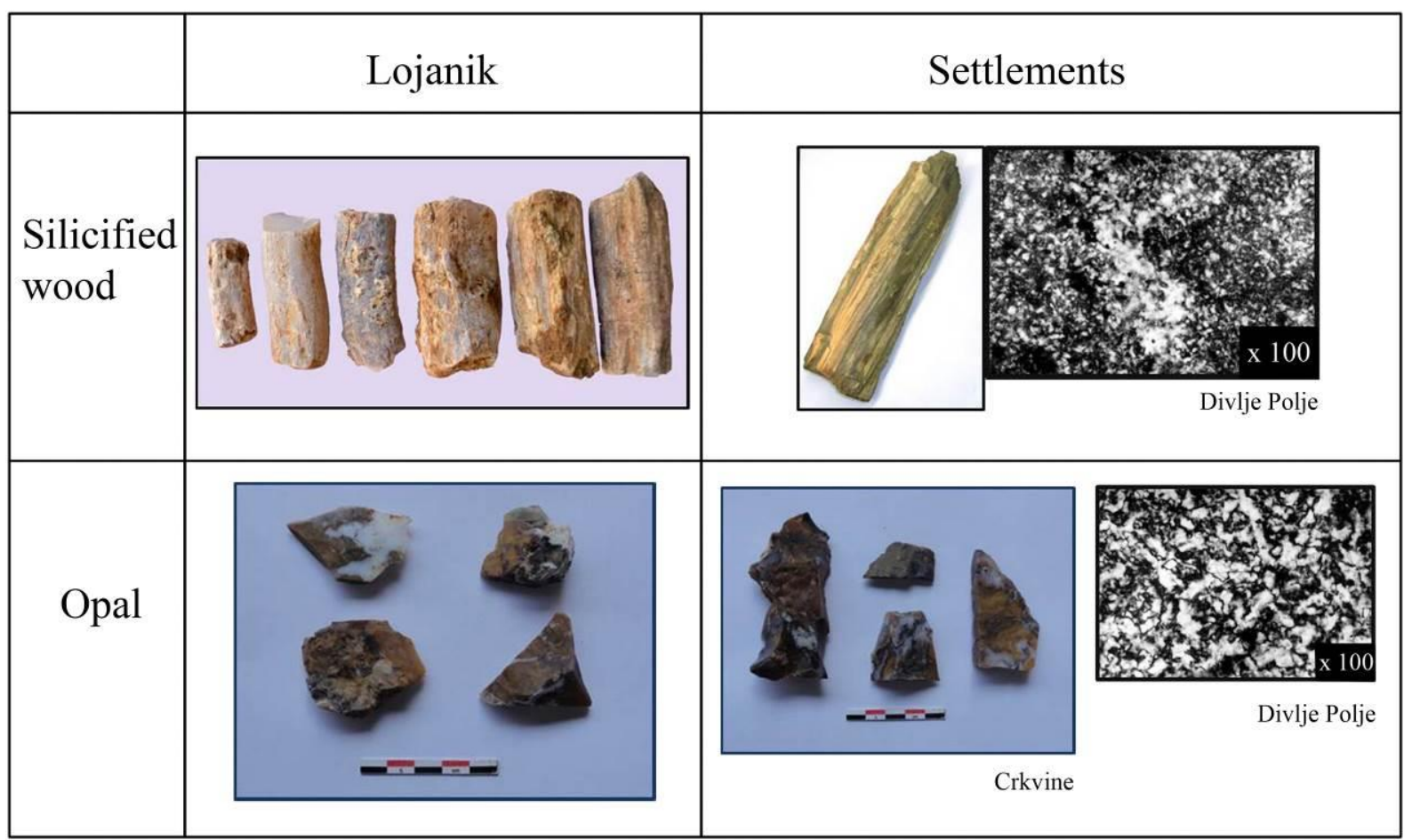

Figure 5. Correlations between raw material from Lojanik and artefacts from Neolithic settlements.

Chronological determination of the finds represents a problem in a certain sense. In general, it can be said that the majority of artefacts belongs to the Palaeolithic and Neolithic periods (Early and Middle Neolithic, and the Early Chalcolithic, as well), but the finds of the preliminary phase of knapping are not so chronologically sensitive.

The mines are still being exploited today, where the focus is on the extraction of silicified wood for sharpening of knives and scythes. Unlike the miners in the past, modern miners are using matt and rough less silicified wood. Such wood parts are very good raw material for grinding and sharpening tools. The interesting fact is that the products of modern mining from Lojanik have in the last three decades been objects of a developed trade between miners and their partners, and the goods have been distributed in the territory of the former Yugoslavia.

\section{The Vlaška Glava site}

The Vlaška Glava site in the village of Samaila is situated on the right bank of the West (Zapadna) Morava River, close to the first slopes of Jelica Mt. and near the city of Kraljevo (Figure 1). This site is located on the third terrace above the river and a part of it is nowadays levelled and used as the burial ground. It occupies the central position in the west central region of Serbia. The research of Vlaška Glava started in 2009 with the survey conducted by the National Museum in Kraljevo and the next year it became a part of the University of Belgrade project ${ }^{2}$. 
Based on their form, the artefacts from the open-air Palaeolithic site Vlaška Glava could be dated within the range from 330,000 to 90,000 years BP, i.e. from the end of the Lower Palaeolithic (not older than the beginning of the isotopic stage 9) to the Middle Palaeolithic, not later than the beginning of the isotopic stage 5 (Mihailović \& Bogosavljević Petrović 2009:43).

In the assemblage of 250 artefacts, denticulated and notched tools, as well as retouched flakes prevail (Figure 6). A few core types were identified, as cores on pebbles of the chopper type, Levallois cores, Kombewa type, 'cobble wedge' cores, and randomly knapped pebbles (Mihailović \& Bogosavljević Petrović 2009).

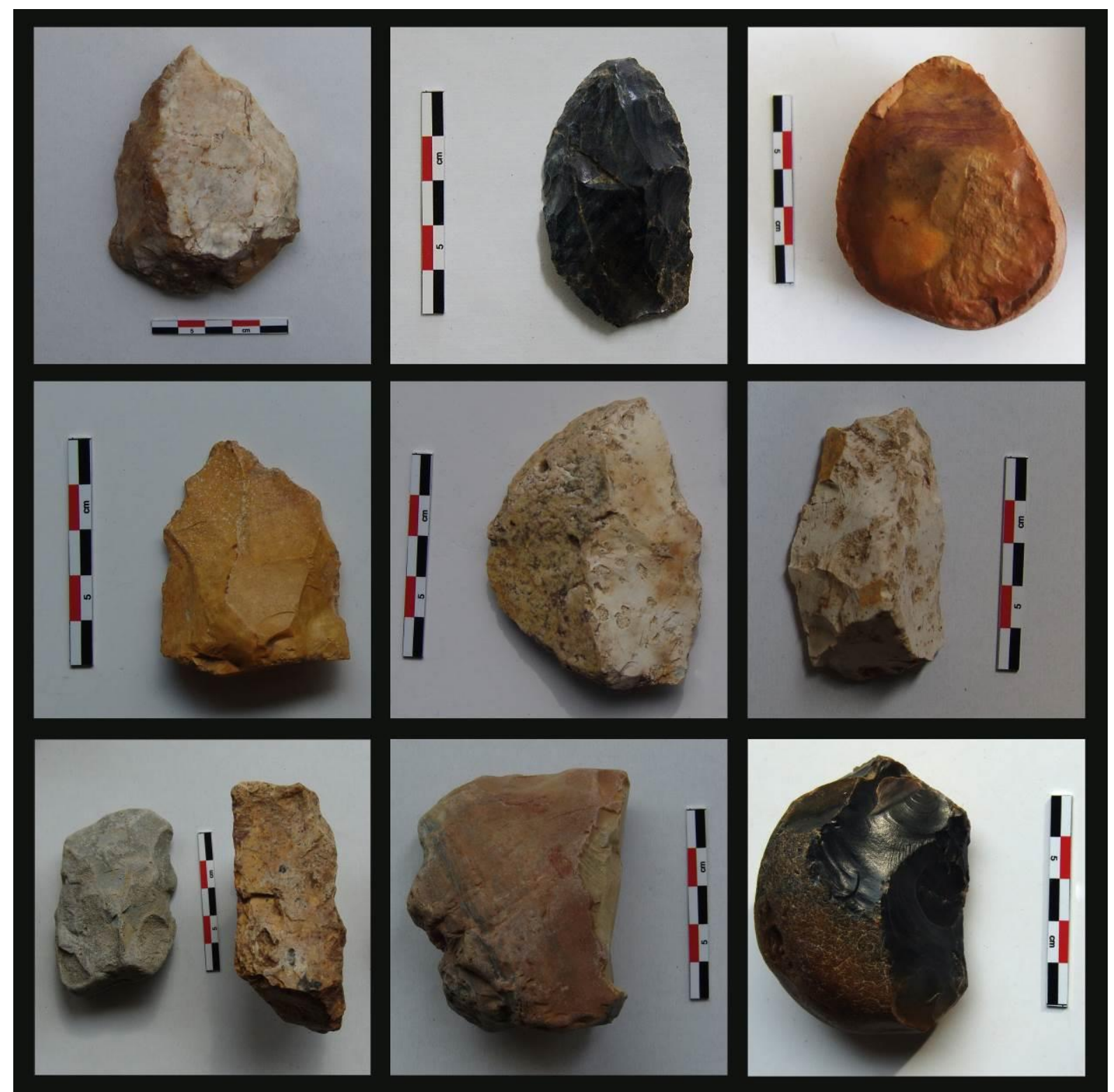

Figure 6. Artefacts from the Vlaška Glava site.

Various kinds of raw material were found at the site $^{3}$. Cherts of white, ochre, red, brown and black colour were petrologically identified as radiolarian or other organogenic cherts. Silicified magnesite was also identified as well as some volcanic and metamorphic rocks.

In the search of the raw material origin, some of the primary and secondary deposits have been investigated so far. In the assemblage from the Vlaška Glava, nearly half of the entire serial consists of fluvial deposit - pebbles from the creek Grabovac, as well as from the West 
Morava river. Subsequent field prospections of the Grabovac showed that some cherts of brown, ochre, and wax honey colour pebble represented raw materials chosen for the production of artefacts at Vlaška Glava. More significant fieldwork was done down the stream of West Morava, where a huge number of samples were collected. In order to make a preliminary determination of their quality, a lot of pebbles were tested by hammering (Figure 7). Macroscopic petrologic characterizations demonstrated a high degree of similarity with the raw materials used for artefact production at Vlaška Glava, too (Figure 8). Regarding the distance, the creek Grabovac flows directly across the site, and the West Morava is only two kilometres away from Vlaška Glava. It is clear that a local aspect of acquisition was the basic concept of raw materials supply.
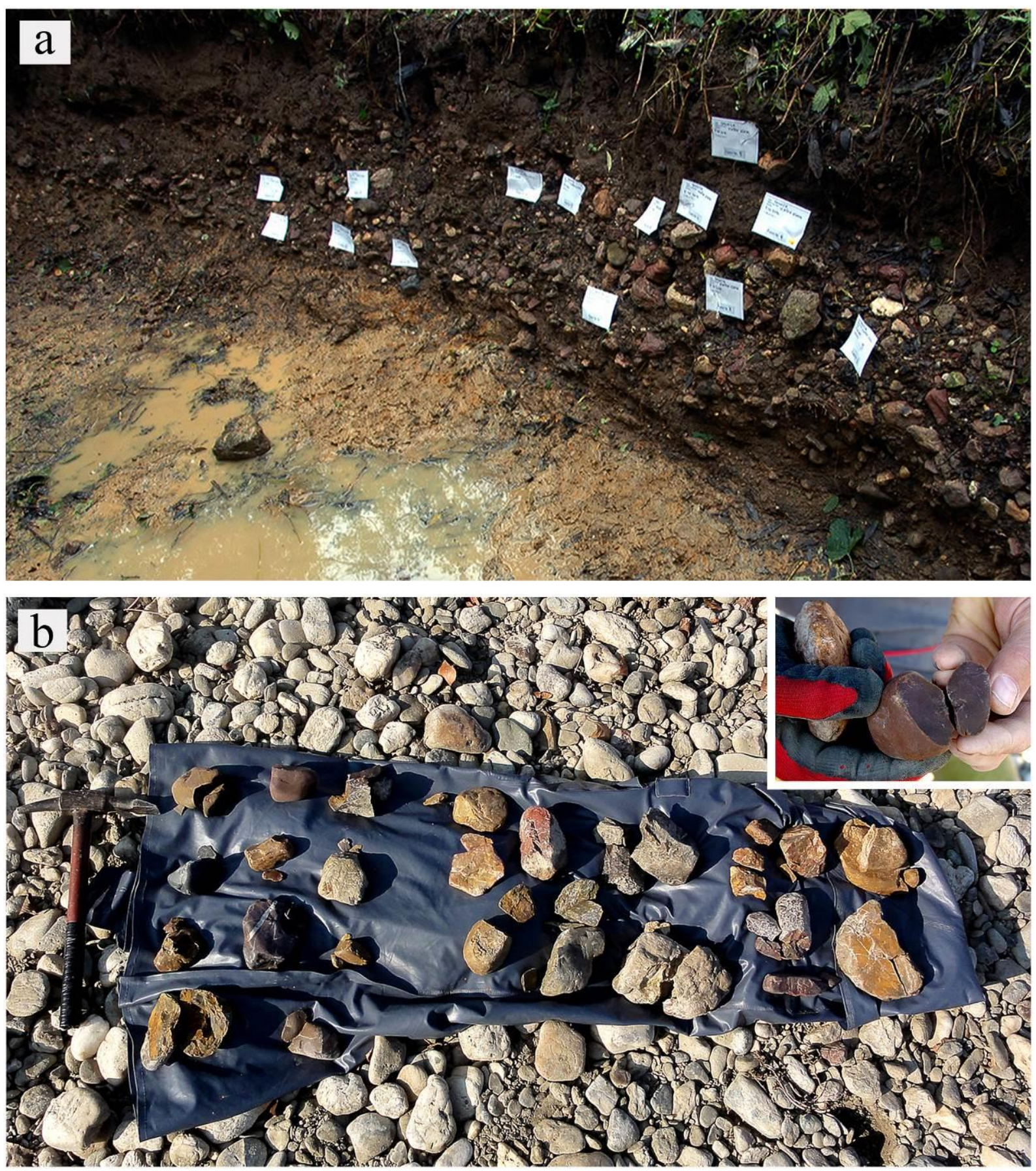

Figure 7. Sampling of secondary deposits. a. Grabovac Creek; b. West Morava River. 


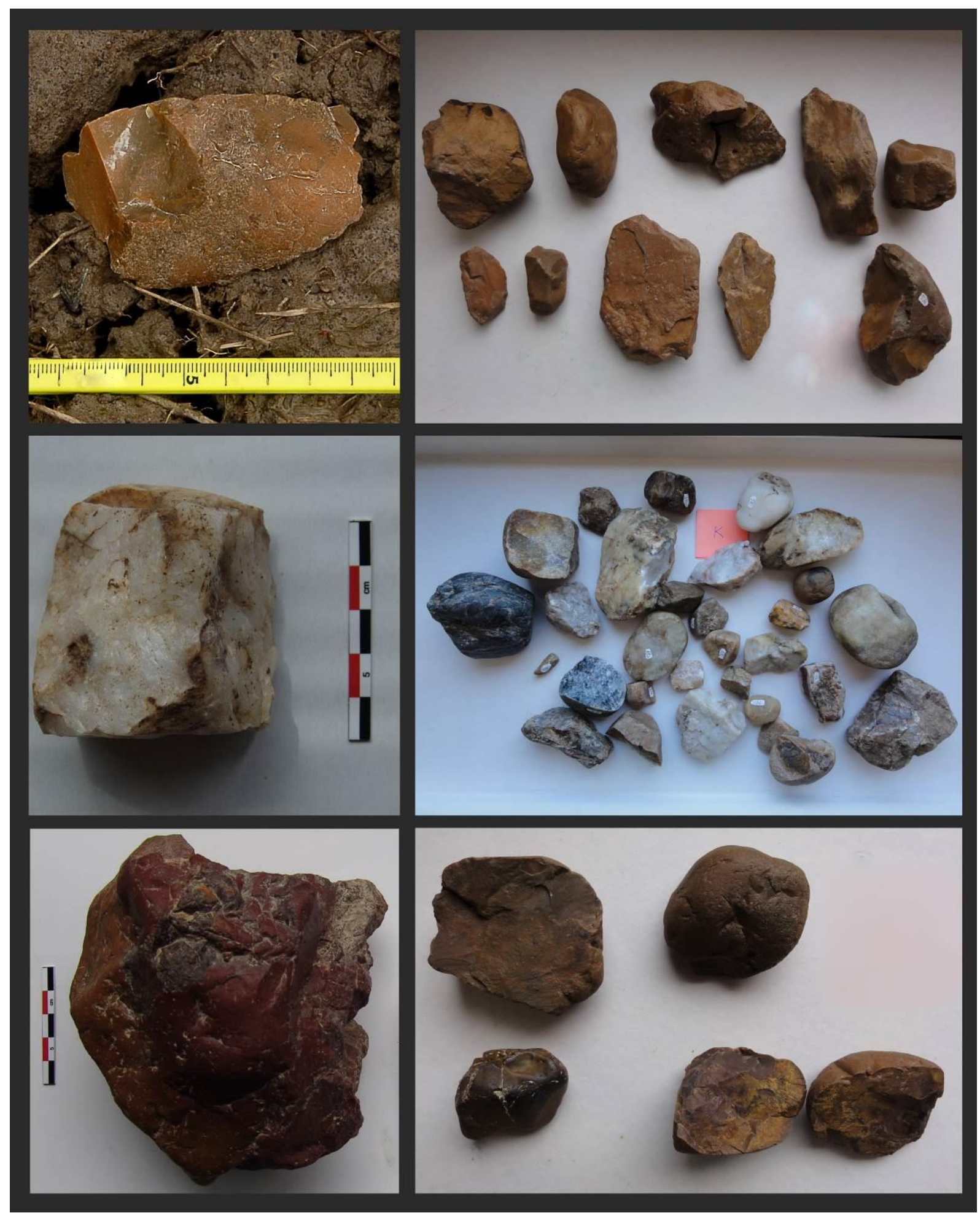

Figure 8. Artefacts from the Vlaška Glava site (left) and their match in the raw material from fluvial deposits (right).

Geologists previously identified diabase-chert formations from the Jurassic period in the western part of the Čačak-Kraljevo basin, in the region of Jelica Mt. (Pavlović et al. 1977:270-275). During the investigation of that natural potential, we found an interesting primary deposit on the northern slopes of the mountain, $9 \mathrm{~km}$ southwest from Vlaška Glava, at the location called Ćosovići (Figure 9). It is an outcrop on the contemporary road (Workshop 1) with high quality bluish grey flint, represented by a surface rock and followed 
by pieces of raw materials, semi-products (biface), pre-cores and pre-forms, debitage and some tools, such as a rudimentary rejuvenation blade (Figure 10). Subsequent analyses showed no match between the artefacts from Vlaška Glava and Workshop 1. Instead, this location was interpreted as a separate unit of the workshop type, directly on the outcrop. It should be emphasized that there are several caves and abris in the vicinity of this outcrop which are potential habitats.

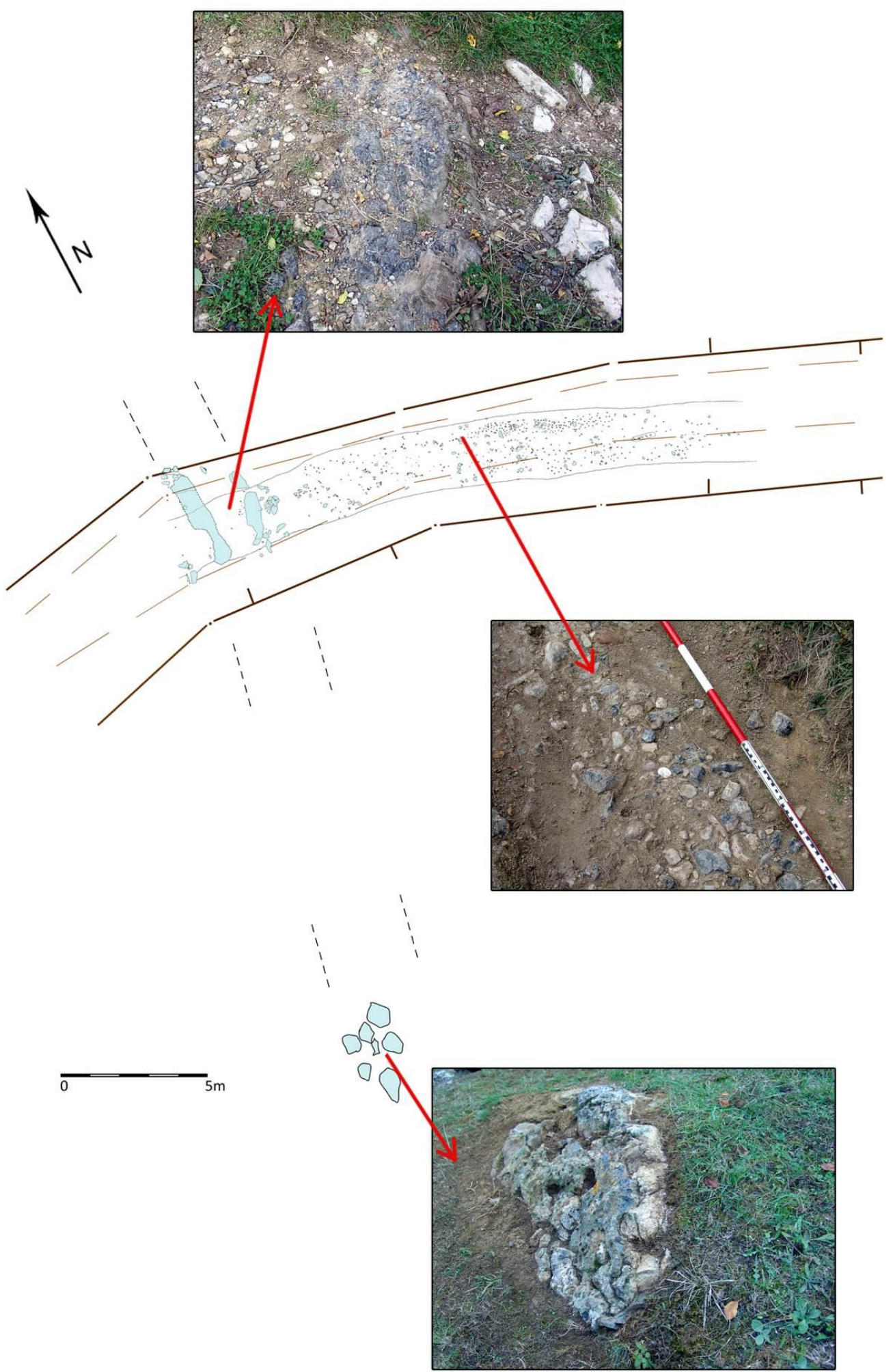

Figure 9. Plan view of workshop I. 

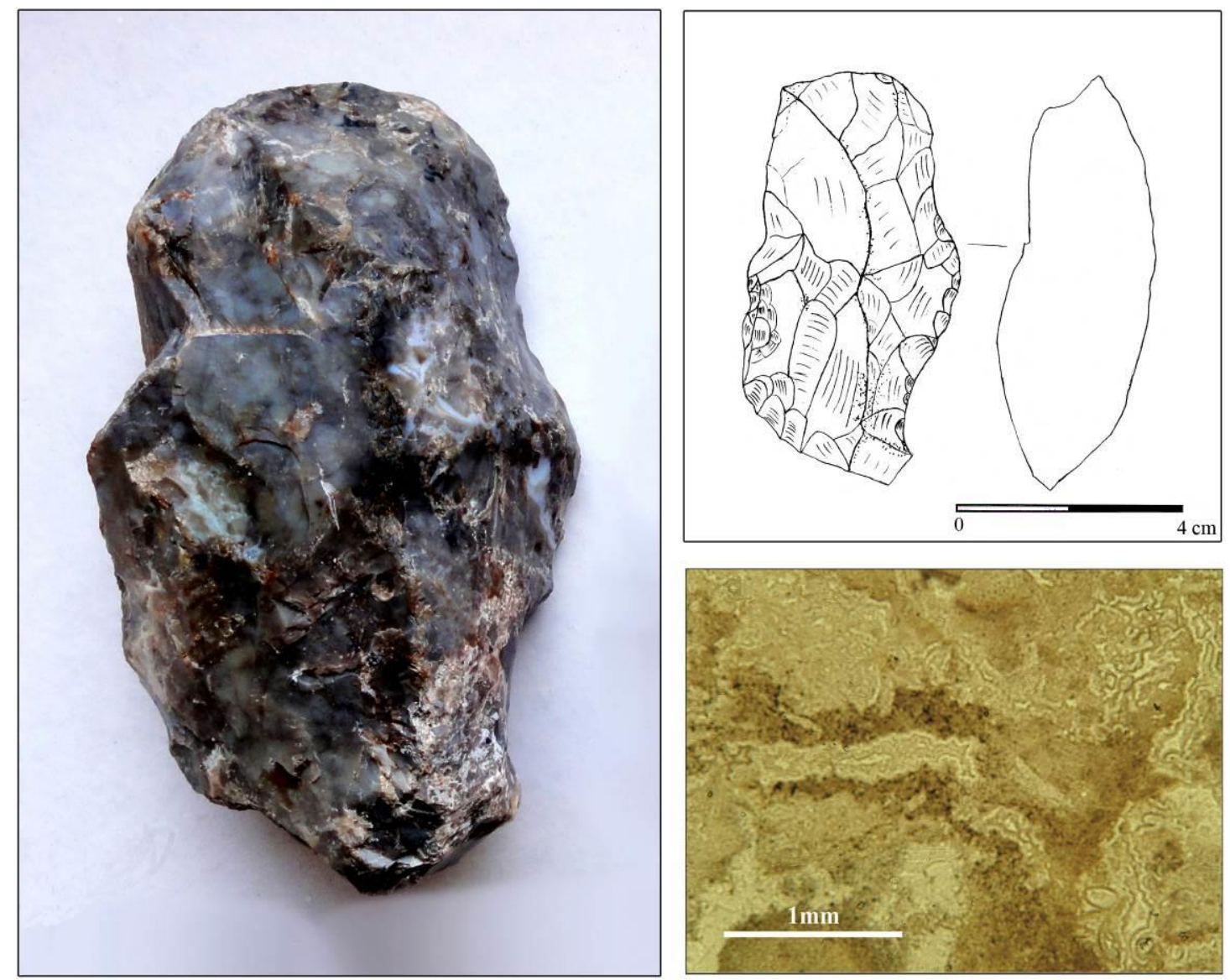

Figure 10. Semiproduct with thin section of bluish grey flint from Workshop I.

\section{The contemporary Lazac magnesite mine}

The Lazac mine is situated in the village of the same name on the northern slopes of Jelica Mt. (Figure 1, 11). It is a contemporary magnesite mine, in the area where many outcrops of this raw material are exploited for the purpose of industrial production. The magnesite ore body to which it belongs represents a sedimentary formation syngenetic with the nearby sandy carbonic series in which is concordant bedded. It is probably Upper to Middle Miocene age (Figure 2). It is a lens form with the length of $90 \mathrm{~m}$, width up to $35 \mathrm{~m}$, northwest - southeast oriented. The very base of the magnesite ore body consists of thick dolomite formation (Popević 1973).

At the beginning of the seventies of the $20^{\text {th }}$ century, the mine was exploited by a local company. Since the research showed that the mineral structure of ore body was not efficient enough for the production of thermosafe bricks, the shafts were closed. The problem was the high percentage of silicon-dioxide $\left(\mathrm{SiO}_{2}\right)$ versus the basic ratio of magnesium, silicified parts of the magnesite ore body (Bogosavljević Petrović \& Marković 2012: Table 1). But, in contrast to the modern situation, this structure of Lazac magnesite represented a striking advantage for the artefact production in the Neolithic (Figure 12). The earliest examples of magnesite artefacts in the Čačak-Kraljevo basin are from the Starčevo culture (Early Neolithic). Identifications of raw material from the Okruglica site at the same time present the first petrologic analysis done in this area. Ground stone tools (adzes and axes) found there are made from allotropic modification of magnesite and silicon-dioxide (Valović 1987:34). In the Vinča culture, the structures of raw material showed the prevalence of magnesite, white opals and cherts in lithic collections. This is especially characteristic for the Late Vinča culture sites in Central Serbia: Divostin, Trsine, Divlje polje and Grivac (Prinz 1988, Mc Pherron 1988, 
Bogosavljević 1991, Bogosavljević Petrović 1999, Antonović 2008, Bogosavljević Petrović 2008).

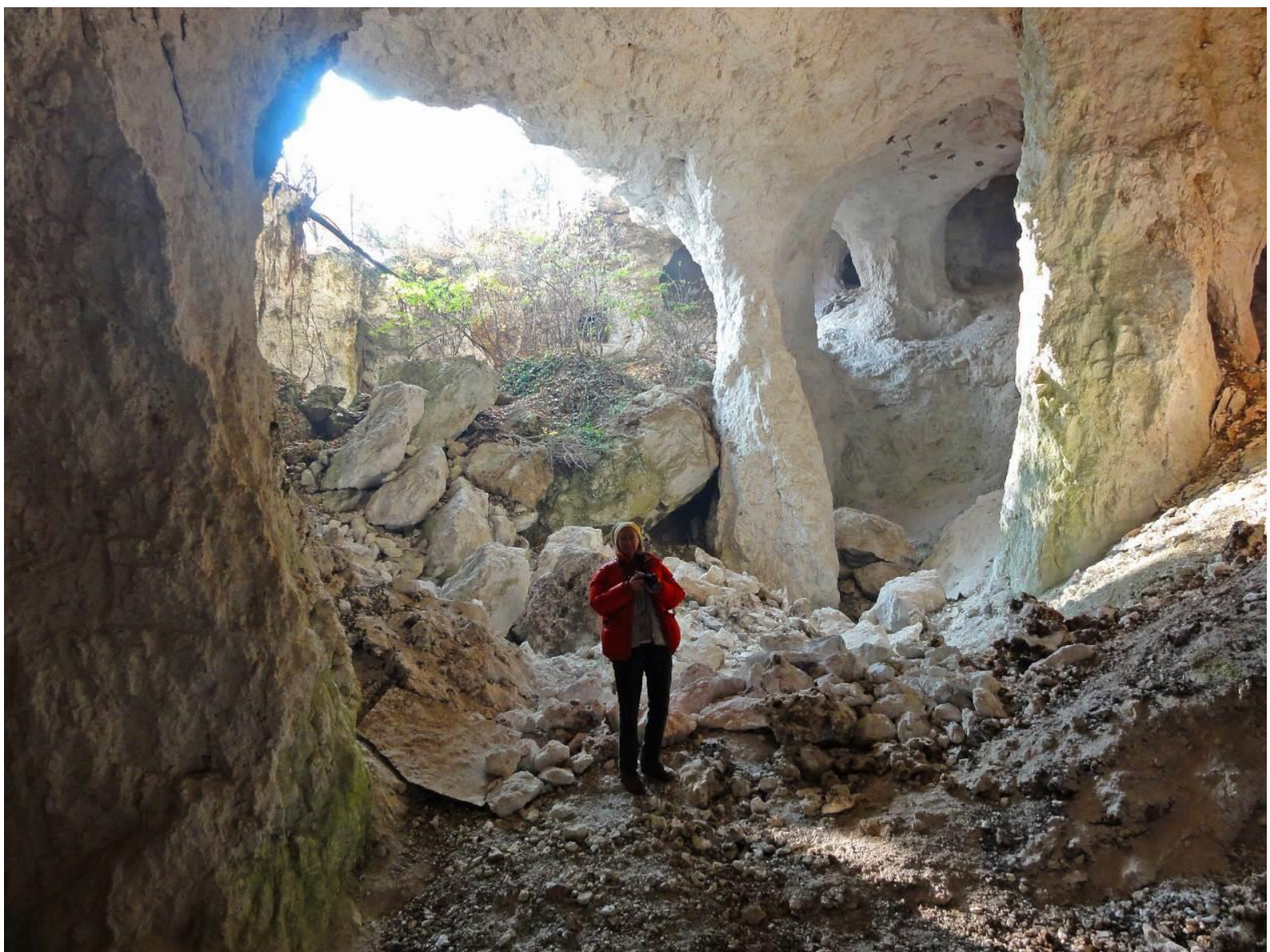

Figure 11. The Lazac mine. Contemporary main hall with collapsed ceiling (in picture, V. Bogosavljević Petrović for approximate scale).

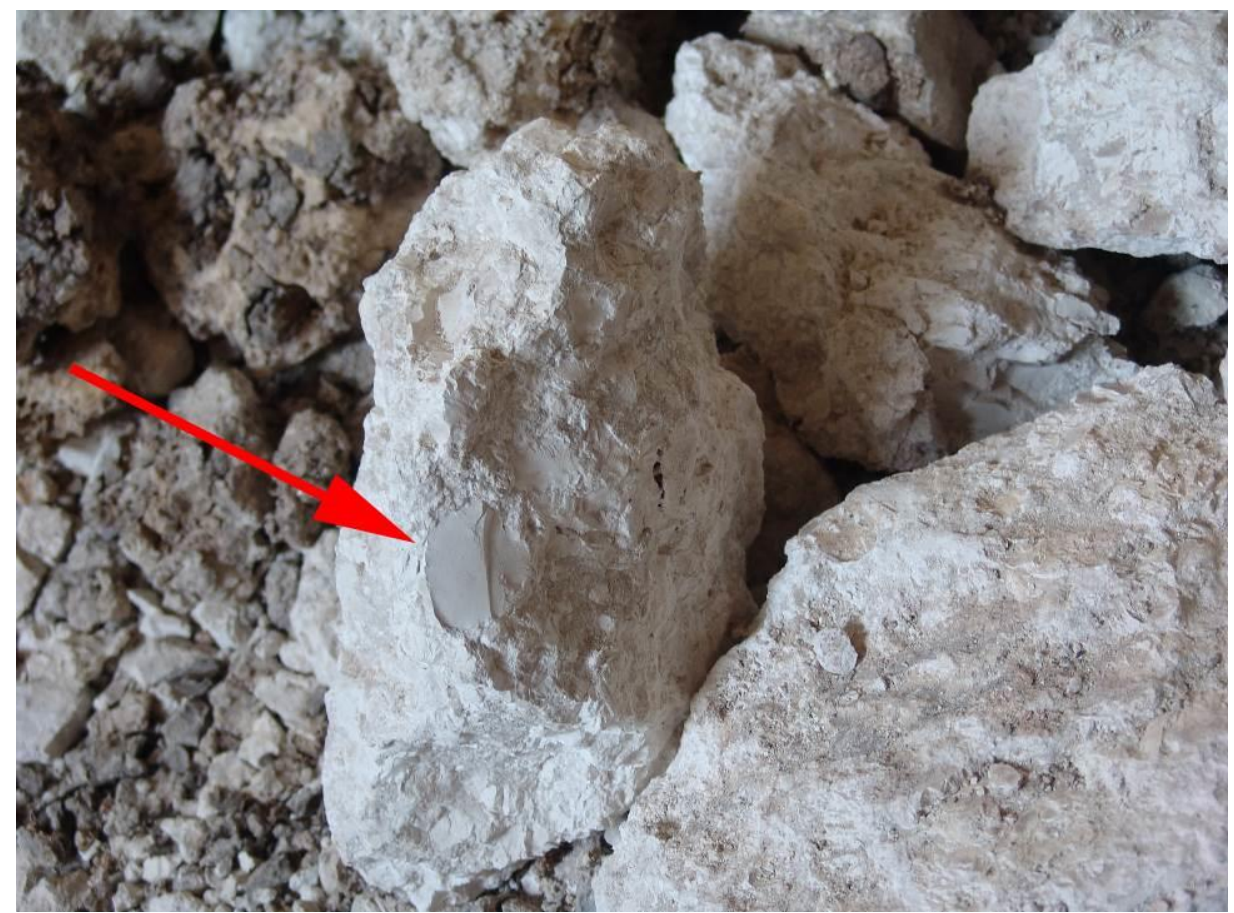

Figure 12. The Lazac mine. Silicified part on a magnesite fragment. 
Besides the raw material studies, the research of the Lazac mine allowed us to make some parallels between ore exploration in the Middle Ages and modern times. A wooden support in the form of the Cyrillic letter P (П) (Figure 13) was noticed at the very entrance of the shaft. The same shape was recorded during the reconstruction of the mediaeval mine Kiževak at Kopaonik Mt. (Bogosavljević et al. 1988). There are much more similarities like the type of wood, solidness of round logs, dimensions, constructive details between the ceiling and the frame.

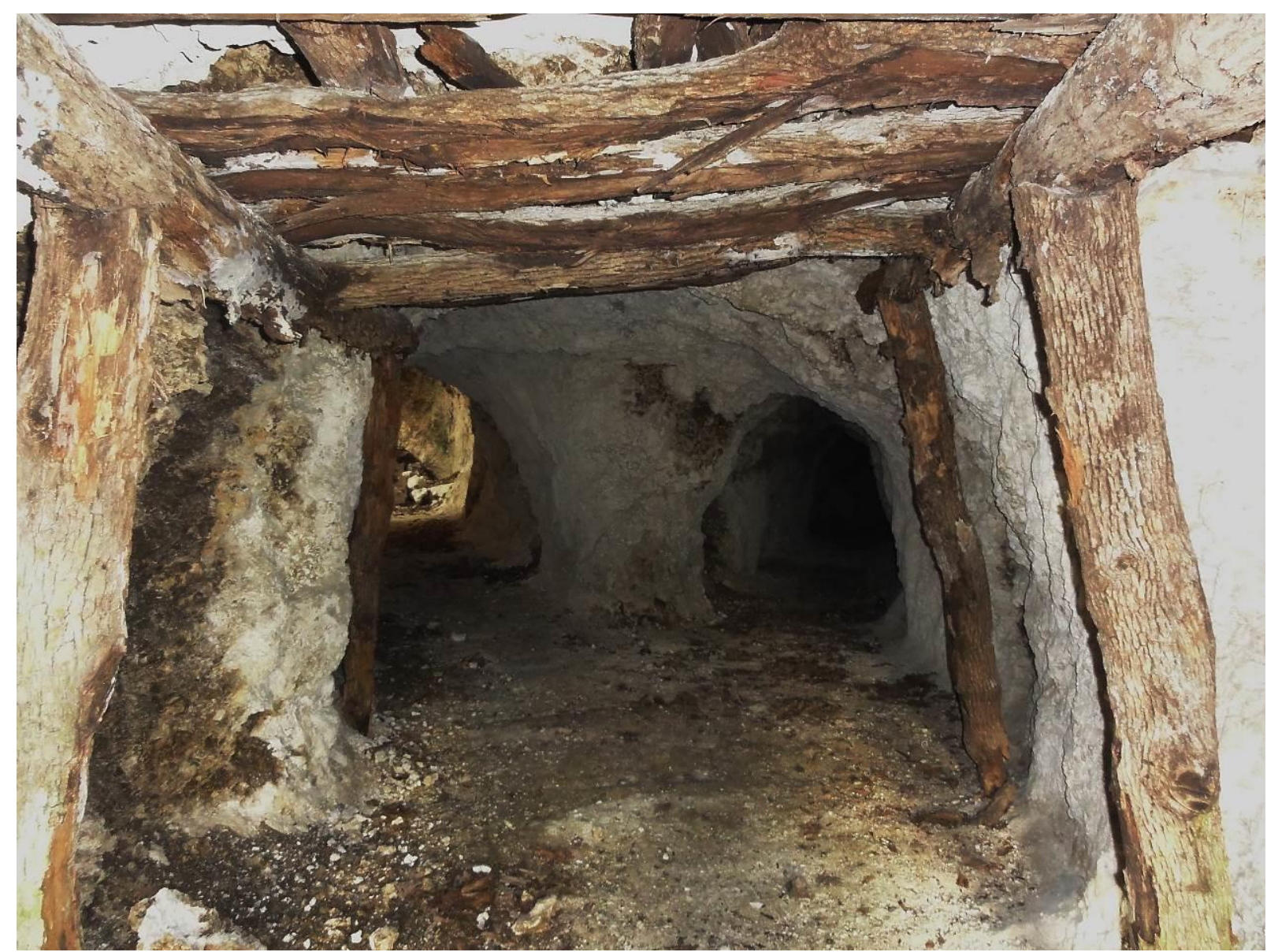

Figure 13. The Lazac mine. Wooden support at the shaft

\section{Concluding remarks}

In the territory of the West Morava basin, there are all elements needed for the study of the stone raw material exploitation strategy. Through the above presented case studies, some of the raw material procurement models were identified (Figure 14).

Links between deposits and settlements are very visible on the example of the Lojanik mine and Neolithic settlements Crkvine and Divlje Polje. Identical sorts of raw material were found on surface mine forms and workshops at Lojanik and in the assemblages of those two settlements. Based on the fact that Crkvine is $2 \mathrm{~km}$ and Divlje Polje $8 \mathrm{~km}$ away from Lojanik, the local procurement was established. This represents a potential network in which raw materials, such as white opal and cherts, varieties of magnesite, silicified wood, and a lot of high-quality cherts and flints of different colour, used to circulate. Based on the samples collected on Lojanik, of which some are artefacts, it can be concluded that the exploitation of raw material have been taking place since Palaeolithic to modern time.

Local procurement was also established at the Lower/Middle Palaeolithic site of Vlaška Glava. Raw materials were gathered from the sources tens of meters to $2 \mathrm{~km}$ (potentially 9 
$\mathrm{km})$ away. That had used to be an ideal situation for ancient population from Vlaška Glava. A dual model of acquisition, from primary and secondary deposits, is recorded. The sourcing of potential geological deposits was conducted simultaneously with the first survey and field exploration of the site. Having in mind a scarce volume of petroarchaeological research in Serbia so far, this represents a great benefit and a novelty.

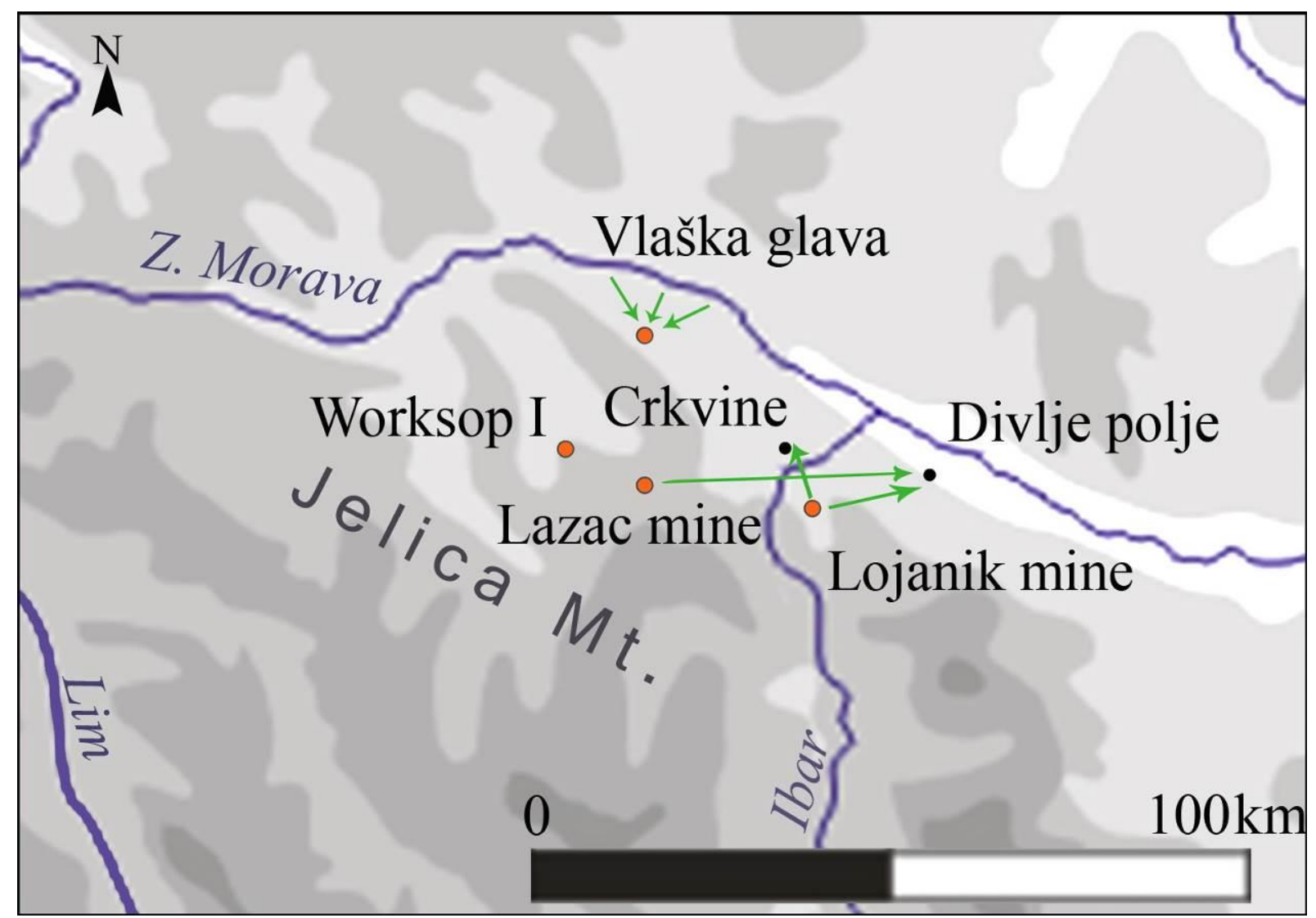

Figure 14. Map of West Central Serbia with case studies of raw material procurement.

The contemporary magnesite mine Lazac has a great importance for the ethnoarchaeological research of West Central Serbia. It can be concluded that it was most certainly a source of magnesite and white opal during the Neolithic. This magnesite with a high percentage of $\mathrm{SiO}_{2}$ was used for artefact production, but was not suitable for industrial use in modern time. Unlike that, the continuity in building in the mediaeval period and the contemporary age was noticed. There are similarities in wooden support systems, types of $\operatorname{logs}$, construction details, etc.

Because of the accumulated number of artefacts, deriving mostly from prehistoric settlements, a striking need for creation of an articulated database, followed by a proper lithotheque, arose. The petroarchaeological database (nearly 6,000 records) made possible sorting of the contents according to sites, type of analysis, kind of material or other parameters, and data cross retrieving, as well (Bogosavljević Petrović \& Marković 2011; 2012). What is essential in this approach is to treat the selected natural stone as an archaeological object (marking, geological and archaeological context definition, etc.), in order to make a link between mines, quarries and outcrops with artefacts from settlements.

After the creation of the database and concept of lithotheque in the National Museum in Belgrade, our main focus was shifted toward a more intensive quest for primary and secondary deposits in a few regions of Serbia. By defining those deposits in the basin of West 
Central Serbia and incorporating the results in the mentioned database and lithotheque, the corpus of data that can be applied in all future raw material studies was created.

\section{Notes}

${ }^{1}$ The project of the National Museum in Belgrade Origin, distribution and interpretation of the stone as raw materials in Neolithic and Chalcolithic of the Central Balkans, since 2010, project director Vera Bogosavljević Petrović.

2 The project of Faculty of Philosophy University of Belgrade Cultural changes and population movement in early prehistory of the Central Balkans, since 2010, project director Dušan Mihailović.

${ }^{3}$ Petrological identifications were done in stages, first by Kristina Šarić (Faculty of Mining and Geology, University of Belgrade), then Divna Jovanović (Geological Survey of Serbia) and finally Vesna Matović (Faculty of Mining and Geology, University of Belgrade).

\section{Acknowledgements}

We would like to thank the colleagues from the National Museum in Kraljevo for their assistance in our research. Also, we are very grateful to Andrej Starović, Jelena Ceriman, Dragana Eremić and Andrija Despotović from the National Museum in Belgrade for their technical assistance in the preparation of this paper.

\section{References}

Antonović, D. 2008 Ground stone artifacts. In: Grivac, settlements of Proto-Starčevo and Vinča culture, (Tasić, N., Ed.), Center for Scientific Research of Serbian Academy of Sciences and Arts and University of Kragujevac and National Museum of Kragujevac, Kragujevac: p. 411-432.

Bogosavljević, V. 1987, Камене секире-чекићи из Народног музеја у Краљеву. Наша прошлост, 2: 9-26. (in Serbian) ("Stone Axes-Hammers at National Museum in Kraljevo")

Bogosavljević, V. 1990, Okresana kamena industrija sa neolitskih naselja Divlje polje $i$ Trsine. Unpublished magister's thesis no. 3/316 at the Department of Archaeology, Faculty of Philosophy, University of Belgrade, 327 p. (in Serbian) ("The chipped stone industry of the Neolithic sites Divlje polje and Trsine")

Bogosavljević, V. 1991, Окресана камена индустрија са неолитског насеља Трсине. Зборник Народног музеја Чачак, 21: 5-36. (in Serbian) (“Chipped stone industry from the Neolithic site of Trsine")

Bogosavljević, V. 1992, Окресана камена индустрија са насеља Дивље поље, Народни музеј у Краљеву, Краљево, 30 p. (in Serbian) (“Chipped stone industry of Divlje Polje site").

Bogosavljević Petrović, V. 1999, Ка проблему идентификације рудничких и радио ничких налазишта камених сировина у периоду неолита и енеолита. Старинар, 49 (1998): 155-166. (in Serbian) ("Contribution to the problem of identification of the stone raw material mining and workshop sites in the Neolithic and Chalcolithic"). 
Bogosavljević Petrović, V. 2008, Flaked Stone industry. In: Grivac Settlements of ProtoStarčevo and Vinča culture, (Tasić, N., Ed.), Center for Scientific Research of Serbian Academy of Sciences and Arts and University of Kragujevac and National Museum of Kragujevac, Kragujevac: p. 355-409.

Bogosavljević Petrović, V. 2005, Праисторијски рудници на централном Балкану. Зборник Народног музеја, 18 (1): 79-113. (in Serbian) ("Prehistoric mines in the central Balkans")

Bogosavljević Petrović \& Marković 2011, Прва петроархеолошка база података Србије. Гласник Српског археолошког друштва, 27: 249-272. (in Serbian) ("The first petroarchaeological database of Serbia")

Bogosavljević Petrović, V. \& Marković, J. 2012, History and current studies of petroarcheological data from the Neolithic and Chalcolithic in Serbia. Bulgarian ejournal of Archaeology, 2(1): 51-66. URL: http://be-ja.org/article/history-and-currentstudies-of-petroarcheological-data-from-the-neolithic-and-eneolithic-in-serbia/

Bogosavljević, V., Mrkobrad, D. \& Bogosavljević, D. 1988: Истраживања средњевековног рударства на западном Копаонику (околина Кижевака). Наша прошлост, 3: 9-45. (in Serbian) ("Research of medieval mining at West Kopaonik mountain - Kiževak area")

ISS 1966, Geological map of Western and North - Western Serbia with neighborhood of Belgrade, Institute of Soil Science, Belgrade.

McPherron, A. 1988, Porcellanite Flakes from Divostin. In: Divostin and Neolithic of Central Serbia, (McPherron, A. \& Srejović, D., Eds.), Narodni muzej Kragujevac and Department of Anthropology, University of Pittsburgh, Pittsburgh and Kragujevac: p. 255-300.

Mihailović, D. \& Bogosavljević Petrović, V. 2009, Самаила - Влашка глава, палеолитско налазиште на отвореном простору. Наша прошлост, 10: 21-43. (in Serbian)

("Samaila - Vlaška glava, open-air palaeolithic site")

Novković, M. 1975, Западноморавски басен. In: Геологија Србије, Vol. 7, (Petković, K., Ed.), Zavod za regionalnu geologiju i paleontologiju Rudarsko - geološkog fakulteta, Univerzitet u Beogradu, Beograd: p. 122-128. (in Serbian) ("West Morava basin")

Pavlović, M. B., Stevanović, P. \& Eremija, M. 1977, Чачанско - краљевачки (или западноморавски) басен. In: Геологија Србије II - 3 (Petković, K., Ed.), Zavod za regionalnu geologiju i paleontologiju Rudarsko - geološkog fakulteta, Univerzitet u Beogradu, Beograd: p. 270-275. (in Serbian) (“Čačak-Kraljevo (or West Morava) basin").

Popević, А. 1973 Завршни извештај о истраживағима седиментних магнезита шире околине Краљева у 1972-оj, Arhiva rudarsko - geološke službe „Magnohrom“, Kraljevo, 43 p. (in Serbian) ("Final report of sediment magnesite research in Kraljevo area").

Prinz, B. 1988, The Ground Stone Industry from Divostin. In: Divostin and Neolithic of Central Serbia, (McPherron, A. \& Srejović, D., Eds.), Narodni muzej Kragujevac and Department of Anthropology, University of Pittsburgh, Pittsburgh and Kragujevac: p. 255-300. 
Stojanović, D. 1987, Минералошко - петролошка детерминација камених секира - чекића из Народног музеја у Краљеву. Наша прошлост, 2: 27-29. (in Serbian) ("Mineralogical - petrologic determination of stone axe-hammers at National Museum in Kraljevo")

Valović, S. 1983, Неолитско насеље у Ратини и његово место у винчанском културном комплексу. Зборник радова Народног музеја, 13: 33-44. (in Serbian) ("The Neolithic settlement Ratina and its place in Vinča culture")

Valović, S. 1987, Округлица - вишеслојни локалитет старчевачке и винчанске културе у Витановцу код Краљева. Наша прошлост, 2: 33-65. (in Serbian) ("The multilayered (Starčevo and Vinča culture) site of Okruglica, Vitanovac, Kraljevo") 
